\title{
New Market Scenarios in Latin America
}

\author{
Judith Mariscal, Carla Bonina and Julio Luna
}

\begin{abstract}
This essay analyzes the role of the market in network expansion in Latin America. Although universal access policies have achieved some degree of success in fighting the digital divide, the issue of massive access to ICT services seems to be more directly associated with the sector's regulatory environment and with the level of competition prevailing in the sector. This essay describes the expansion process of the major operators in Latin America - Telefónica Spain and Teléfonos Mexico - as a result of regulatory policies implemented in their countries of origin. It evaluates the sector's performance after the reforms carried out in the region, as well as the role of mobile telephone services as the driving force in offering access to population segments that had no previous service. And, lastly, within this new market and technological context, it is suggested that there is a need to design policies that turn challenges into new opportunities to encourage network expansion towards areas without services. Thus, within this new scenario, research lines are identified to carry out regulatory policies and contribute to the enrichment of their design.
\end{abstract}


This essay analyzes the role played by the market, as well as by competition and its regulation in network expansion in Latin America. Although universal access programs implemented in the region have achieved varying degrees of success in fighting the digital divide (García Murillo \& Kuerbis, 2004), the issue of massive access to information and communication technologies (ICT) seems to be closely related to the sector's regulation, the market's development and the level of competition prevailing in the sector.

Developing countries have faced the challenge of expanding access to the telecommunications network through two kinds of policies. The first type of policy aims to create a competitive market that stimulates investment, lowers fees and encourages ICT access. The second kind of policy emphasizes a direct role of the public sector in providing access to the population through subsidized programs.

These two kinds of policies reflect the need to fight two phenomena, which the World Bank has called the Market Gap and the Access Gap. The Market Gap refers to the difference between the penetration level that could be reached under non-optimal market conditions and under optimal conditions. The Access Gap refers to the unavoidable market failures where some population groups are not serviced because their access is not considered profitable.

This essay analyzes the role played by the market in the network expansion in Latin America. More than a decade has gone by since Latin American governments put a pro-market reform within the telecommunications sector into action. In general terms, these reforms have contributed to encouraging the adoption of technology, to expanding service access and to lowering its costs. However, the regulatory models adopted in the region have not yet been able to fully achieve the objectives set forth during this process. In particular, the lack of ICT access is still a significant problem for the lower income population segments. Moreover, although the more general objectives related to the development of the sector remain unchanged, technological innovation and the market context have significantly changed the industry scenario. These changes exert a growing pressure on the traditional models and pose new challenges.

With regard to the market, today, the region experiences a consolidation of two major actors that compete against each other in practically all Latin American countries. While the Spanish company Telefónica consolidated a strong position in many countries within the region starting in the mid-90s, the Mexican company Telmex and its subsidiary América Móvil have recently developed a strong acquisition policy within the local and mobile telephone sectors. These measures pose serious concerns regarding the future of competition in the region. The current regulatory models are still trying to adjust to the improved practices of a scheme that 
believes the sector can work by increasing its level of competition through a large number of operators. Reality makes us face a different situation, not only a market concentration, but the clear presence of a regional duopoly. Although the operators are already implementing corporate strategies in this new context, the regulators do not seem to have adjusted their policies to this scenario.

In addition, technological innovation has brought about an uneven development of the different market segments, where mobile telephone services have adopted a predominant role in the region. Today, among the population with fewer resources, mobile telephone services represent the main form of access to telecommunications services. The technological convergence opens the possibility of offering similar services through different means. The regulation of technologies associated to a service must be re-evaluated.

The first part of this essay illustrates the expansion process of the two main operators in Latin America as a result of regulatory policies implemented in their countries of origin. The second part of this paper assesses the performance of the sector after the reforms implemented in the region. The third and last section of this essay analyzes the role of mobile telephone services as the driving force to give access to previously unattended population segments. Lastly, once this new market and technology context is described, this essay suggests the need to generate policies that turn new challenges into opportunities to encourage network expansion towards unattended areas. In this regard, research lines are identified to contribute to the enrichment of regulatory policy design within this new scenario.

\section{The Expansion of Telefónica and América Móvil ${ }^{1}$}

Reforms to the telecommunications sector carried out in Spain and Mexico during the 90s favored the creation of two major companies, placing them in a predominant position in all segments of this market. The strategy implemented in both cases was the result of policies that aimed at creating National Champions. The success of these policies made the globalization of these companies possible.

In the case of Spain, with the imminent access of the European Community Market, the Spanish government implemented policies supporting Telefónica in order for it to face competition. However, Spanish telecommunications needed to be updated the most compared to other European countries, making it highly probable that the company would be acquired by major European operators or, in the best possible scenario, that it would play a subordinate role within integrated European telecommunication services. In order to anticipate this possibility, the Spanish government chose to transform Telefónica into a National Champion.

\footnotetext{
${ }^{1}$ This section is based on Mariscal \& Rivera (2005).
} 
The goal of creating a National Champion was reestablished as a specific telecommunication policy objective in the document "Líneas estratégicas de las políticas de telecomunicaciones para el período de transición" (Strategic Trends in Telecommunication Policies for the Transitional Period). This document asserts the need "to reinforce national operators for them to face competitors from other countries" and proposes to favor the technological and industrial development of the national telecommunications sector.

The regulatory framework established a generous price policy along with a credit policy of "cheap money" and the decision of not distributing dividends. During the first half of the 90s, the price policy aimed at financing the company's modernization and re-balancing its fees. Telefónica benefited from the Spanish government's support through strong financing mechanisms. ${ }^{2}$ Telefónica began to acquire

Table 1.1 - Telefónica's World Positioning By Services

\begin{tabular}{|c|c|c|c|c|c|c|}
\hline Country & $\begin{array}{l}\text { Local } \\
\text { Telephone } \\
\text { Services }\end{array}$ & $\begin{array}{l}\text { Long-Distance } \\
\text { Telephone } \\
\text { Services }\end{array}$ & $\begin{array}{l}\text { Mobile } \\
\text { Telephone } \\
\text { Services }\end{array}$ & Internet & Data & $\begin{array}{c}\text { Public } \\
\text { Telephone } \\
\text { Services }\end{array}$ \\
\hline \multicolumn{7}{|l|}{ Spain } \\
\hline \multicolumn{7}{|l|}{ Argentina } \\
\hline \multicolumn{7}{|l|}{ Brazil } \\
\hline \multicolumn{7}{|l|}{ Chile } \\
\hline \multicolumn{7}{|l|}{ Mexico } \\
\hline \multicolumn{7}{|l|}{ Peru } \\
\hline \multicolumn{7}{|c|}{ Source: Own study based on data from Telefónica's Web site and information submitted by the company. } \\
\hline \multicolumn{7}{|c|}{ Market Participation in Selected Countries } \\
\hline Country & \multicolumn{2}{|c|}{ Fixed Lines } & & \multicolumn{2}{|c|}{ Mobile Users } & \\
\hline Spain & \multicolumn{2}{|c|}{$52,3 \%$} & & \multicolumn{2}{|l|}{$52,8 \%$} & \\
\hline Argentina & \multicolumn{2}{|c|}{$55,8 \%$} & & \multicolumn{2}{|l|}{$24,4 \%$} & \\
\hline Brazil & \multicolumn{2}{|c|}{$33,7 \%$} & & \multicolumn{2}{|l|}{$20,9 \%$} & \\
\hline Chile & \multicolumn{2}{|c|}{$73,5 \%$} & & \multicolumn{2}{|l|}{$29,8 \%$} & \\
\hline Mexico & \multicolumn{2}{|l|}{-} & & \multicolumn{2}{|l|}{$9,2 \%$} & \\
\hline Peru & \multicolumn{2}{|c|}{$99,6 \%$} & & \multicolumn{2}{|l|}{$55,1 \%$} & \\
\hline
\end{tabular}

Source: Own study based on data from Telefónica's Web site. It includes the recent acquisition of mobile operations by Bellsouth in Latin America announced in March 2004. The table does not include less significant company operations in Latin America.

\footnotetext{
${ }^{2}$ This policy was not exclusive of the telecommunications sector, and was also developed in other sectors, such as the infrastructure and banking sectors.
} 
companies with market power and exclusivity periods in Argentina, Chile, Peru and Brazil (Table 1.1). In these countries, the reforms were made in a context of fiscal crisis, which led to prioritizing fiscal revenues over the creation of a competitive environment, which in turn resulted in an advantage to the buyers. The acquisition process opened an exclusive market in Latin America for the company, which in terms of number of consumers was much larger than the Spanish market. These new markets had an important growth potential, since telephone density was extremely low and the proximity between the three new Latin American markets helped in order to take advantage of economies of scope and of scale.

In the case of Mexico, in 1990 (and as a vital part of the country's modernization program), Telmex was privatized and sold as a vertically integrated company. Achieving a successful privatization meant to overcome all political and economic hurdles faced by policy-makers. A vertically integrated company served the objective of meeting the demands of the key players in the system: the national private sector and the unions, who lobbied against dismantling the company and favored the creation of a National Champion. In addition, policy-makers considered that dividing Telmex would take longer, during a period when time was a key factor to determine the success of the modernization program. Telmex was financially strengthened, making it more attractive to investors, and was sold in 1990 to the joint venture between the Mexican consortium Grupo Carso, Southwestern Bell and France Telecom. Later on, Grupo Carso began to acquire shares, becoming the major shareholder in Telmex-América Móvil.

The Mexican group Telmex-América Móvil did not play a significant role at the beginning of the privatization process in Latin America. Operations focused their attention on the Mexican company's modernization efforts. The country's great growth potential, given a penetration of little over $6 \%$ in fixed telephone services, made this option viable. The priority was to strengthen the company and to prepare it for future competition as a result of the eventual entry of powerful U.S. operators into the country.

Its interest in the Latin American telecommunications sector began during the second half of the 90s, and followed two different paths: i) acquisitions of privatized fixed telephone companies in Guatemala, El Salvador and Nicaragua, and, most importantly, ii) the expansion of their mobile telephone operations in several countries in South America (Table 1.2). 
Table 1.2: Telmex América Móvil World Positioning Per Services

\section{Telmex-América Móvil 2003-2004}

Telmex (1) - América Móvil (2) Positioning

\begin{tabular}{|l|c|c|c|c|c|c|}
\multicolumn{1}{|c|}{ Country } & $\begin{array}{c}\text { Local } \\
\text { Telephone } \\
\text { Services }\end{array}$ & $\begin{array}{c}\text { Long-Distance } \\
\text { Telephone } \\
\text { Services }\end{array}$ & $\begin{array}{c}\text { Mobile } \\
\text { Telephone } \\
\text { Services }\end{array}$ & Internet & Data & $\begin{array}{c}\text { Public } \\
\text { Telephone } \\
\text { Services }\end{array}$ \\
\hline Argentina (1,2) & & $\checkmark$ & $\checkmark$ & $\checkmark$ & $\checkmark$ & \\
\hline Brazil (1,2) & $\checkmark$ & $\checkmark$ & $\checkmark$ & $\checkmark$ & $\checkmark$ & \\
\hline Chile (1) & $\checkmark$ & $\checkmark$ & & $\checkmark$ & $\checkmark$ & \\
\hline Colombia (1,2) & & & $\checkmark$ & $\checkmark$ & $\checkmark$ & \\
\hline Ecuador (2) & & & $\checkmark$ & & & \\
\hline $\begin{array}{l}\text { El Salvador, Honduras } \\
\text { and Nicaragua (2) }\end{array}$ & $\checkmark$ & $\checkmark$ & $\checkmark$ & & $\checkmark$ & \\
\hline Guatemala (2) & $\checkmark$ & $\checkmark$ & $\checkmark$ & $\checkmark$ & $\checkmark$ & \\
\hline Mexico (1, 2) & $\checkmark$ & $\checkmark$ & $\checkmark$ & $\checkmark$ & $\checkmark$ & $\checkmark$ \\
\hline Peru (1) & $\checkmark$ & $\checkmark$ & & $\checkmark$ & $\checkmark$ & \\
\hline
\end{tabular}

Note: (1) Indicates Telmex's presence, (2) América Móvil's presence and $(1,2)$ both company's presence in each case.

\section{América Móvil's Market Share in Latin America At the end of 2004}

\begin{tabular}{|l|c|}
\hline Country & Mobile Market Share (\% of Users) \\
\hline Argentina & 27.8 \\
\hline Brazil & 25.6 \\
\hline Chile & -- \\
\hline Colombia & 57.5 \\
\hline Ecuador & 63.9 \\
\hline El Salvador & 32.2 \\
\hline Guatemala & 45.6 \\
\hline Honduras & 28.3 \\
\hline Mexico & 75.6 \\
\hline Nicaragua & 58.1 \\
\hline Panama & -- \\
\hline Peru & -- \\
\hline Uruguay & 1.0 \\
\hline Venezuela & -- \\
\hline
\end{tabular}

Source: Own study based on América Móvil's 2004 Annual Report. 
In contrast to Telefónica, which built its competitive position in Latin America by acquiring local fixed telephone services in several countries and soon after or even simultaneously entered other segments, Telmex and América Móvil first entered those markets with mobile and long-distance telephone services. In many countries the rate of mobile telephone penetration has exceeded the rate of fixed telephone services, reducing the need to control the fixed telephone services local loop. Perhaps it is even more important that mobile telephone services are beginning to offer broadband Internet access, with a quality that can compete with DSL or Cable TV technology. Moreover, Telmex-América Móvil's strategy for the region was not limited to mobile or long-distance telephone services, but it also had a global strategy that included local fixed telephone services.

Telefónica has followed an aggressive expansion policy in recent years. The most important acquisition has been the franchise of local fixed telephone services in Brazil, which has led to control of one third of the telephone lines in Latin America's biggest country. At the same time, it has acquired all of Bellsouth's mobile telephone operations in Latin America. With this acquisition, Telefónica reached 55 million mobile telephone users in the region at the end of 2004 (Table 1.3). Moreover, Telefónica has entered the Mexican mobile market and controls $14.8 \%$ of total users in that country. (Table 1.4).

Table 1.3: Telefónica's Worldwide Results for 2004

\begin{tabular}{|l|c|c|c|c|}
\hline \multicolumn{2}{|l|}{ Grupo Telefónica 2004 Revenues and Users } \\
\hline Country & Spain & Other Countries & Total & \% var 04-03 \\
\hline Revenues (1) & $24,753.0$ & $16,296.8$ & $41,049.8$ & 6.8 \\
\hline Lines in Service (2) & $19,835.3$ & $23,414.3$ & $43,249.5$ & 5.2 \\
\hline Cellular Users (3) & $18,977.0$ & $55,465.4$ & $74,442.5$ & 43.6 \\
\hline
\end{tabular}

(1) In million of Dollars.

(2) Thousands of lines in service: It includes all lines in service from Telefónica Spain, Telefónica CTC Chile, Telefónica Argentina, Telefónica Peru, Telesp, Telefónica Móviles El Salvador, Telefónica Móviles Guatemala and Telefónica Deutschland.

(3) Thousands of mobile users: It includes all cellular users of Telefónica Servicios Móviles Spain, MediTelecom, Telefónica Móvil Chile, TCP Argentina, Telefónica Móviles Peru, Brasilcel (Joint Venture with Portugal Telecom in Brazil), Telefónica Móviles Guatemala, Telefónica Móviles El Salvador, Telefónica Móviles Mexico and the operators acquired from BellSouth in Latin America (Venezuela, Guatemala, Nicaragua, Panama, Ecuador, Colombia, Peru and Uruguay).

Source: Grupo Telefónica 2004 Annual Report 
In 2004, América Móvil from Mexico and Telefónica Móviles from Spain operated in 15 Latin American countries, with a joint share in some countries of over $90 \%$ such as in the case of Nicaragua, Colombia, Ecuador and Mexico (Table 1.4). This indicates the presence of a regional duopoly.

Table 1.4: Country Presence and Market Share of América Móvil vs. Telefónica Móviles, 2004

\begin{tabular}{|l|c:c|c|c|}
\hline Telefónica Móviles vs. América Móvil 2004 Market Share & \\
\hline Country / Segment & $\begin{array}{c}\text { AMX } \\
(\%)\end{array}$ & $\begin{array}{c}\text { TEM } \\
(\%)\end{array}$ & $\begin{array}{c}\text { AMX+TMX } \\
(\%)\end{array}$ & $\begin{array}{c}\text { Country's } \\
\text { Mobile Density }\end{array}$ \\
\hline Argentina & 27.8 & 26.1 & 53.8 & 34 \\
\hline Brazil & 25.6 & 49.8 & 75.5 & 37 \\
\hline Chile & -- & 35.1 & 35.1 & 61 \\
\hline Colombia & 57.5 & 32.6 & 90.1 & 23 \\
\hline Ecuador & 63.9 & 30.8 & 94.7 & 28 \\
\hline El Salvador & 32.2 & 23.9 & 56.1 & 23 \\
\hline Guatemala & 45.6 & 26.2 & 71.8 & 23 \\
\hline Honduras & 28.3 & -- & 28.3 & 10 \\
\hline Mexico & 75.6 & 14.8 & 90.4 & 36 \\
\hline Nicaragua & 58.1 & 40.4 & 98.4 & 13 \\
\hline Panama & -- & 73.1 & 73.1 & 12 \\
\hline Peru & -- & 51.9 & 52.0 & 15 \\
\hline Uruguay & 1.0 & 35.6 & 36.7 & 16 \\
\hline Venezuela & -- & 45.7 & 45.7 & 30 \\
\hline
\end{tabular}

Note: AMX: América Móvil, TEM: Telefónica Móviles. Mobile Density represents total mobile density for the country.

Source: Telecom-CIDE based on information from the companies and regulators' Web pages.

Even when Telefónica arrived first in the majority of the countries, the acquisition process of América Móvil and Telmex has modified the configuration of the market in such a way that, although Telefónica continues to have a greater presence in terms of number of countries and users, América Móvil and Telmex continue expanding into new markets. At the end of 2004, Grupo Telefónica reported significantly higher revenues than Telmex - América Móvil's joint operations. However, the growth rates of the Mexican company are larger in the 2003-2004 fiscal year (Tables 1.3 and 1.5). In the fixed telephone services segment, Telefónica continues to hold the dominant position in the region, followed by Telmex, which concentrates the majority of its operations in Mexico. Currently, Telefónica leads in the 
fixed, mobile and broadband markets in Brazil, Argentina, Chile, Peru and Venezuela, while América Móvil and Telmex have a clear dominance in the same segments in Mexico and Central American countries. In 2005, América Móvil and Telmex have acquired new companies in Brazil, Nicaragua, Honduras, Colombia, Venezuela and Chile. This year, the total net increase of users for América Móvil in the region exceeded 7 million users, while Telefónica's total net increase was 4.5 million users. In the case of Mexico, during the same period, Telefónica reported a loss of 200,000 users.

Table 1.5: Telmex-América Móvil 2004 Results in Latin America

\begin{tabular}{|l|c|c|c|c|}
\hline \multicolumn{2}{|l|}{ América Móvil 2004 Revenues and Users } & \\
& Mexico & Other Countries & Total & $\%$ var 04-03 \\
\hline Revenues from Operations (1) & $6,352.0$ & $5,733.0$ & $12,085.0$ & 49.1 \\
\hline Lines in Service (2) & -- & $1,896.0$ & $1,896.0$ & 17.1 \\
\hline Mobile Customers (3) & $28,851.0$ & $32,258.0$ & $61,109.0$ & 39.2 \\
\hline Telmex 2004 Revenues and Users & Mexico & Other Countries & Total & $\%$ var 04-03 \\
\hline & $11,034.2$ & $1,409.9$ & $12,444.1$ & 12.9 \\
\hline Revenues from Operations (4) & $17,172.3$ & No Data & $17,172.3$ & 9.5 \\
\hline Lines in Service (5) & & & & \\
\hline
\end{tabular}

(1) In million of Dollars.

(2) Thousands of lines in service. It includes the number of fixed lines in El Salvador, Nicaragua and Guatemala.

(3) Thousands of mobile customers: It includes all customers in Mexico, United States, Guatemala, El Salvador, Honduras, Nicaragua, Colombia, Ecuador, Brazil, Uruguay and Argentina.

Source: América Móvil 2004 Annual Report.

(4) In million of Dollars.

(5) Thousands of lines in service.

Source: Telmex 2004 Annual Report.

The reform of the telecommunications sector in Latin America has resulted in the unexpected consolidation of two operators that seem to turn the market into a regional duopoly. This poses serious concerns for the development of competition, since a duopoly can generate oligopoly-like practices. Experience has shown that a larger number of operators generate greater competition, and the latter is more efficient in promoting the sector's development by lowering prices, improving quality and expanding the infrastructure (Li \& Colin, 2002; Gutiérrez, 2003; Wallsten 2000, 2001).

In their expansion process, both companies have proven to be able to operate strategically and defeat their competitors. In several countries, policies aimed at 
controlling their expansion and market power have had little success. It would seem reasonable to expect market segmentation strategies and an alliance between both companies; however, this does not seem to be the case until now, since both companies have continued with an expansion process in the same countries and market segments. This phenomenon could be associated to cultural and organizational differences in both companies. While Telmex is vertically operated from Mexico, all of Telefónica's companies report to Spain, and, in some degree, they have underestimated the capacity of the Mexican company to challenge Telefónica's power in Latin America. Today what we can observe is a global survival strategy. In fact, both companies have sacrificed profits in several countries (as shown in the following section) and are taking advantage of the economies of scale and of scope created by their size and regional positioning. As long as the Latin American market is still growing, either from unmet demand or from demand for new services, it is foreseeable that competition and not collusion will prevail.

\section{The Sector's Performance}

Certainly the impact of the reform on the telecommunications sector has been positive. The sector's performance, measured by traditionally used indicators, shows that this market has made major progress in increasing its levels as well as its growth

Figure 2.1: Fixed Teledensity Evolution in Latin America 1990-2003

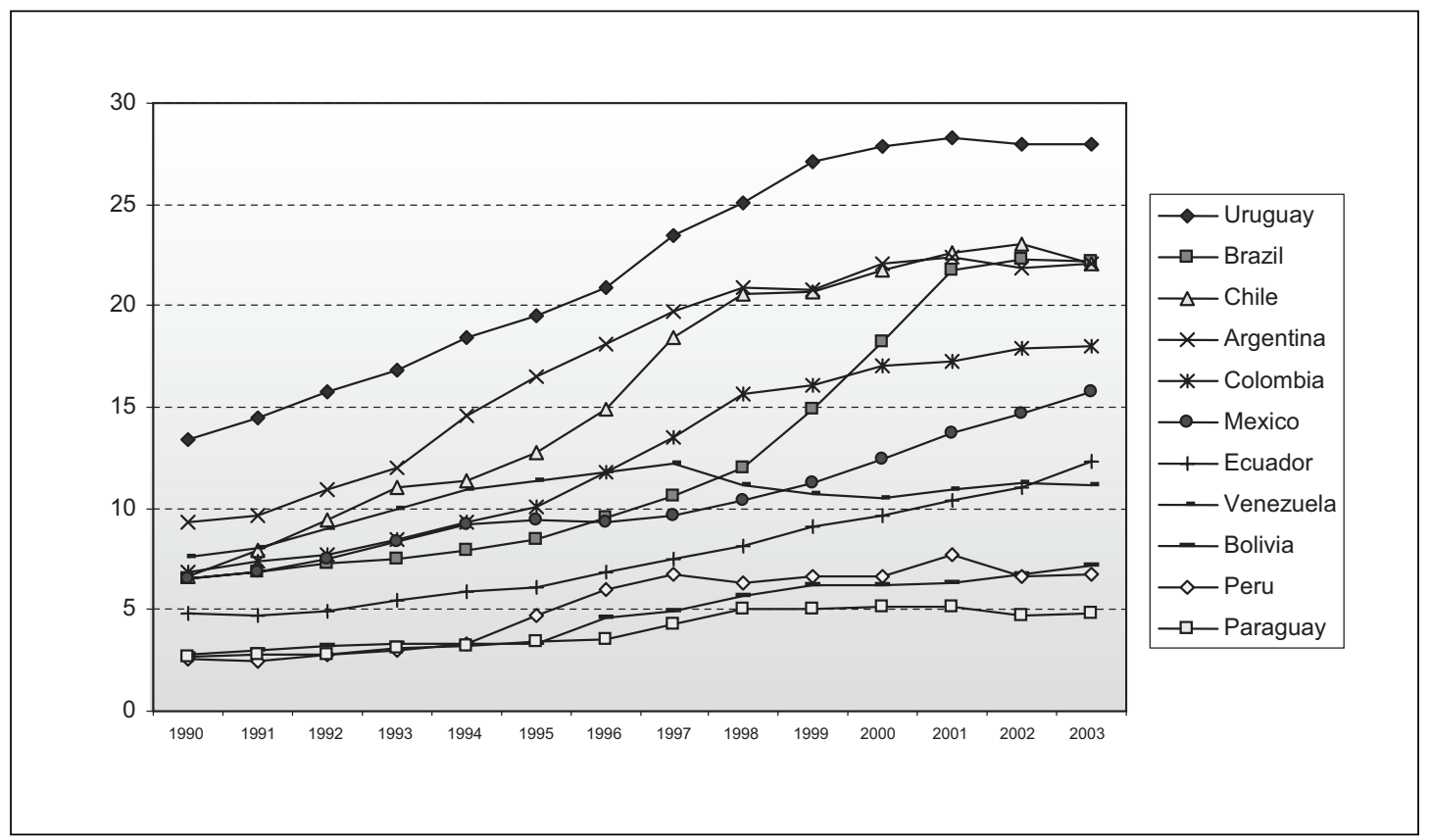

Sources: Telecom Data-CIDE based on ITU World Telecommunication Indicators 2004 and World Development Indicators 2004. 
rates. During the 90s, the period when the first series of telecommunication reforms took place, the Latin American economy exhibited a modest positive performance in its economic growth of close to $2 \%$ averaged among the 11 main economies in the region, led by Argentina, Chile and Uruguay. Despite this moderate growth, the modernization efforts in the region translated into the privatization and financial liberalization processes that led to a record growth in telephone services, with an average annual growth rates of over $12 \%$. As shown in Figure 2.1, telephone density doubled in the region on average terms during this period.

Figure 2.1: Telephone Lines per Employee - Comparison between Latin America and the European Union

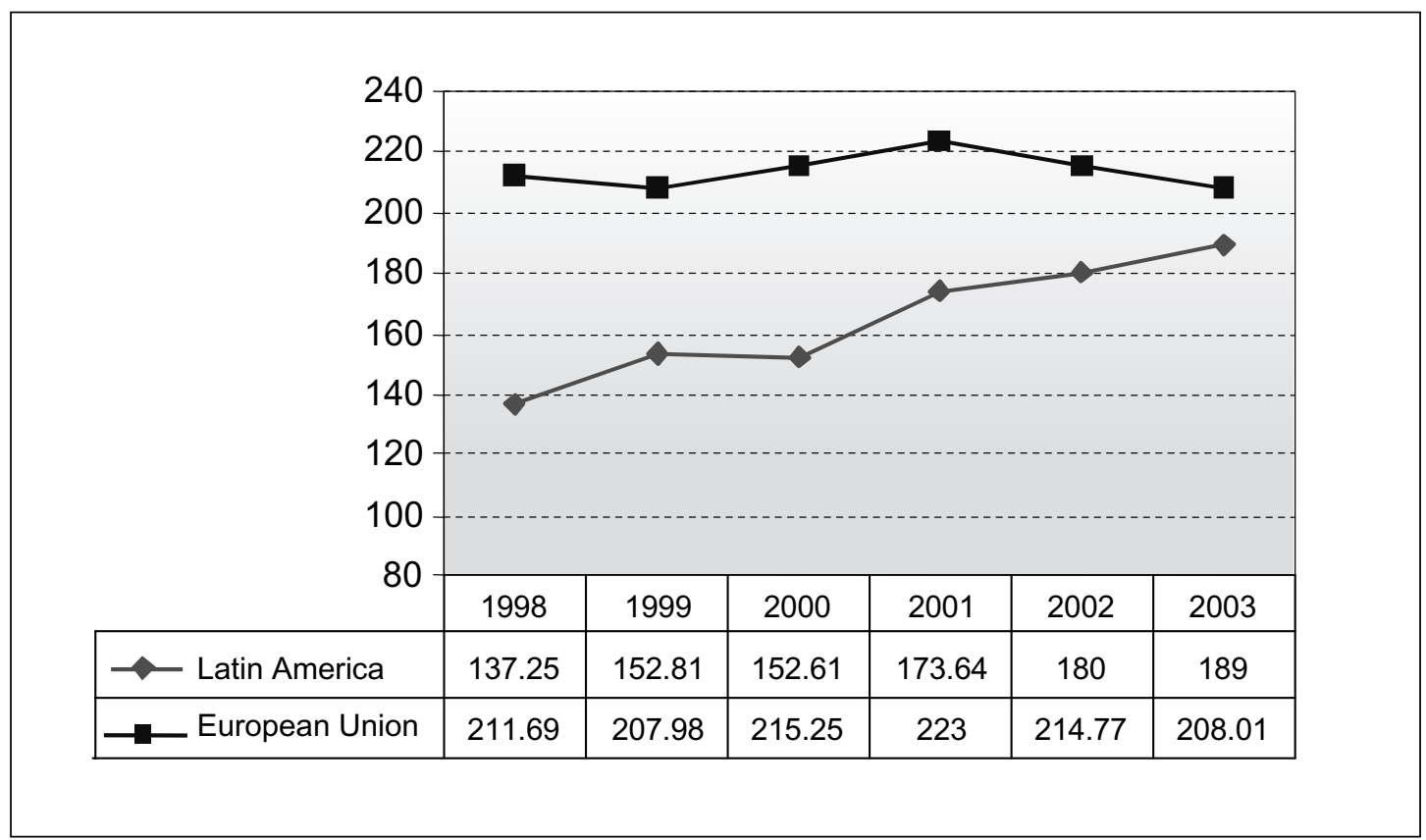

Sources: Telecom Data-CIDE based on ITU World Telecommunication Indicators 2004 and World Development Indicators 2004 .

Along with the increase in teledensity, the improvements made in network modernization and the efficiency in the companies' operations added to the benefits brought about by reforms. In terms of technological adoption, by the end of the decade the percentage of digital lines in the region exceeded $90 \%$. Figure 2.2 shows the companies' productivity. The number of lines per employee also point towards an accelerated growth path that tends to reach efficiency levels similar to those of European markets. In addition, tariffs have shown a tendency to decrease in most market segments. 
However, the objectives of the reform have been unevenly reached among the different countries and within each country's regions. The results of the privatization, with different modalities and timing, were better in Chile (the first country to privatize), Brazil (among the last ones to privatize) and finally Uruguay where, in a nationalistic impulse, refused to privatize but made extraordinary advances in indirect ways, reaching the highest fixed telephone service density of the region by the end of the decade (28\%). On the other hand, the region's poorer countries - Bolivia, Peru and Paraguay - kept the lowest penetration levels of the region, below $6 \%$, during the entire period.

Table 2.1 Fixed Teledensity from the Perspective of Revenues in Latin American Countries

\begin{tabular}{|l|c|c|c|}
\hline \multicolumn{1}{|c|}{ Country } & $\begin{array}{c}\text { pcGDP } \\
\text { U.S.\$95 2003 }\end{array}$ & $\begin{array}{c}\text { Gini Index } \\
\mathbf{2 0 0 0}\end{array}$ & $\begin{array}{c}\text { Fixed } \\
\text { teledensity 2003 }\end{array}$ \\
\hline Uruguay & 4,953 & .45 & 28 \\
\hline Brazil & 4,182 & .58 & 22 \\
\hline Chile & 6,051 & .57 & 22 \\
\hline Argentina & 6,601 & .52 & 18 \\
\hline Colombia & 2,352 & .58 & 16 \\
\hline Mexico & 4,682 & .55 & 12 \\
\hline Ecuador & 1,855 & .44 & 11 \\
\hline Venezuela & 2,470 & .49 & 7.2 \\
\hline Bolivia & 939 & .45 & 7 \\
\hline Peru & 2,431 & .50 & 5 \\
\hline Paraguay & 1,235 & No Data & 28 \\
\hline
\end{tabular}

Source: Telecom Data-CIDE based on ITU World Telecommunication Indicators 2004 and World Development Indicators 2004.

Table 2.1 shows the inequalities among countries in terms of fixed telephone service expansion for 2003. The inequalities in performance do not seem to correspond to unequal wealth, as could be expected. Brazil, which had a very similar income to Mexico that year, reached a teledensity of 22 lines per 100 inhabitants, while Mexico had 16 lines. In turn, Chile, with a lower GNP per capita, also reached 22 lines per 100 inhabitants.

In addition, within the countries, the achievements in terms of penetration and access are also very uneven. There is an internal growth gap between regions with higher access in contrast to those with lower telephone penetration levels, showing 
rates well below the national average. It is noticeable that this limitation caused by inequalities within countries' is observed across the region. Most of the infrastructure is concentrated in the metropolitan area of the capital city, in contrast to the marginal services offered in rural areas (Figure 2.3). For example, in the case of Mexico and Argentina, some provinces regions show low penetration levels, such as the case of Chiapas and Chaco, with six times less teledensity than the capital cities and metropolitan areas. The most dramatic case continues to be Peru, where in 2003 the region of Lima had a close to 30 times higher penetration level close than the province of Huanavelica, with a fixed teledensity of 0.48 .

Figure 2.3: Internal Gap in Telephone Services (\% of Teledensity) - Selected Countries in Latin America, 2003

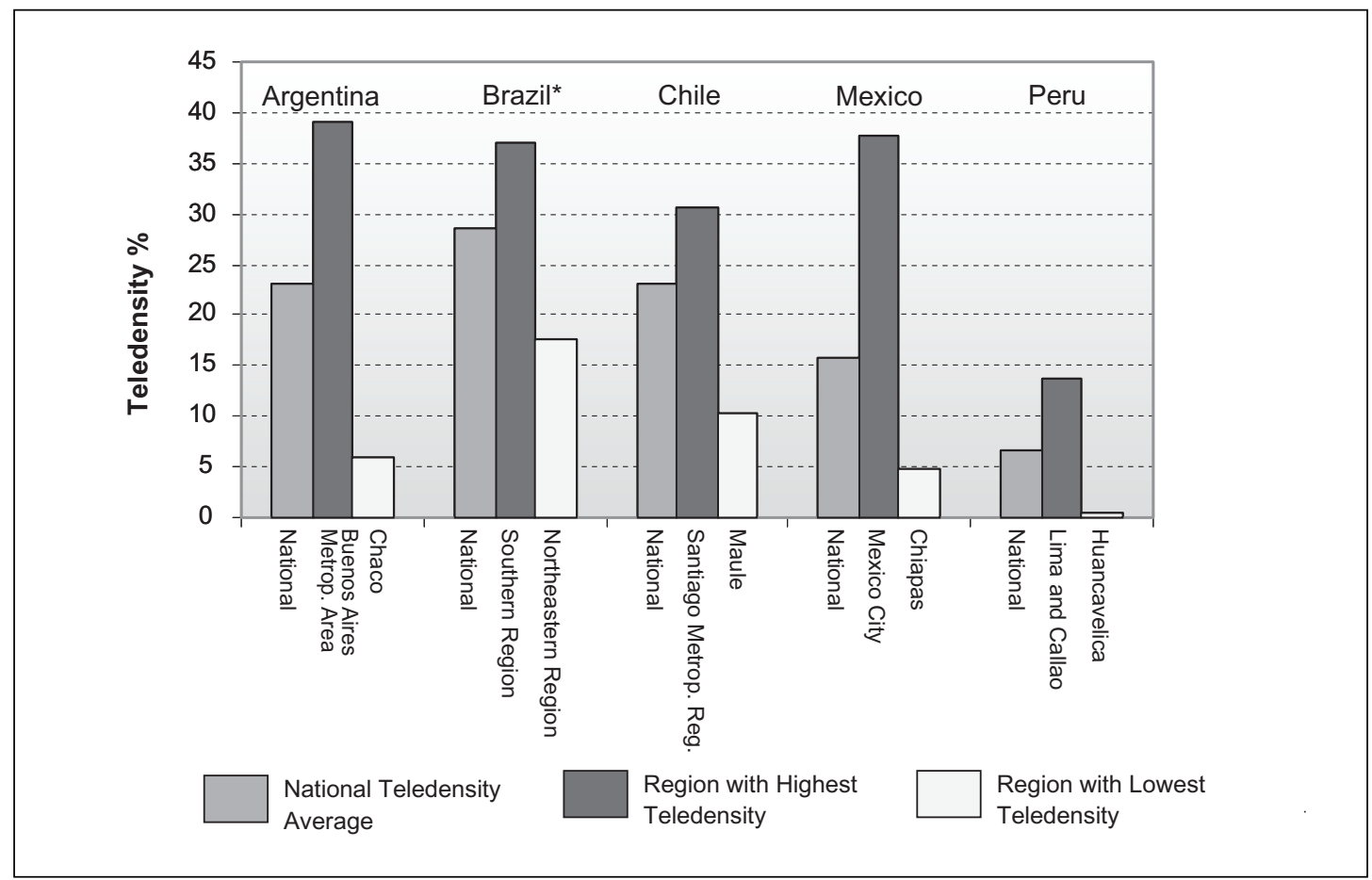

Source: Own study based on date from: CNC (Argentina), Anatel (Brazil), Subtel (Chile), Cofetel (Mexico) and MTC (Peru). Data from end of 2003. *Note: Brazil: Data for 2002.

There is ample literature on descriptive and empirical studies that discuss the issue of performance differences based on the reforms implemented. Outcomes are consistent with the conventional consensus and we know that competition continues to be the best mechanism to encourage the sector's development by increasing penetration and lowering fees (Wallsten, 2000). In addition, privatization by itself 
does not cause the same impact if not combined with the creation of an independent regulator ( $\mathrm{Li} \& \mathrm{Xu}, 2002$ ). Empirical studies indicate that the most important variables to explain the sector's performance are the level of competition, the sequence in policy implementation and the exclusivity periods granted (Wallsten, 2000).

The region's performance, measured by the growth in fixed density, has slowed down and has been stagnant since 1998 as can be observed in Figure 3.1. This was caused, among other reasons, by the exclusivity periods, the high costs of installing the network and the lack of profitability of the service in rural areas. During the

Figures 2.4 and 2.5 - Market Concentration and Teledensity
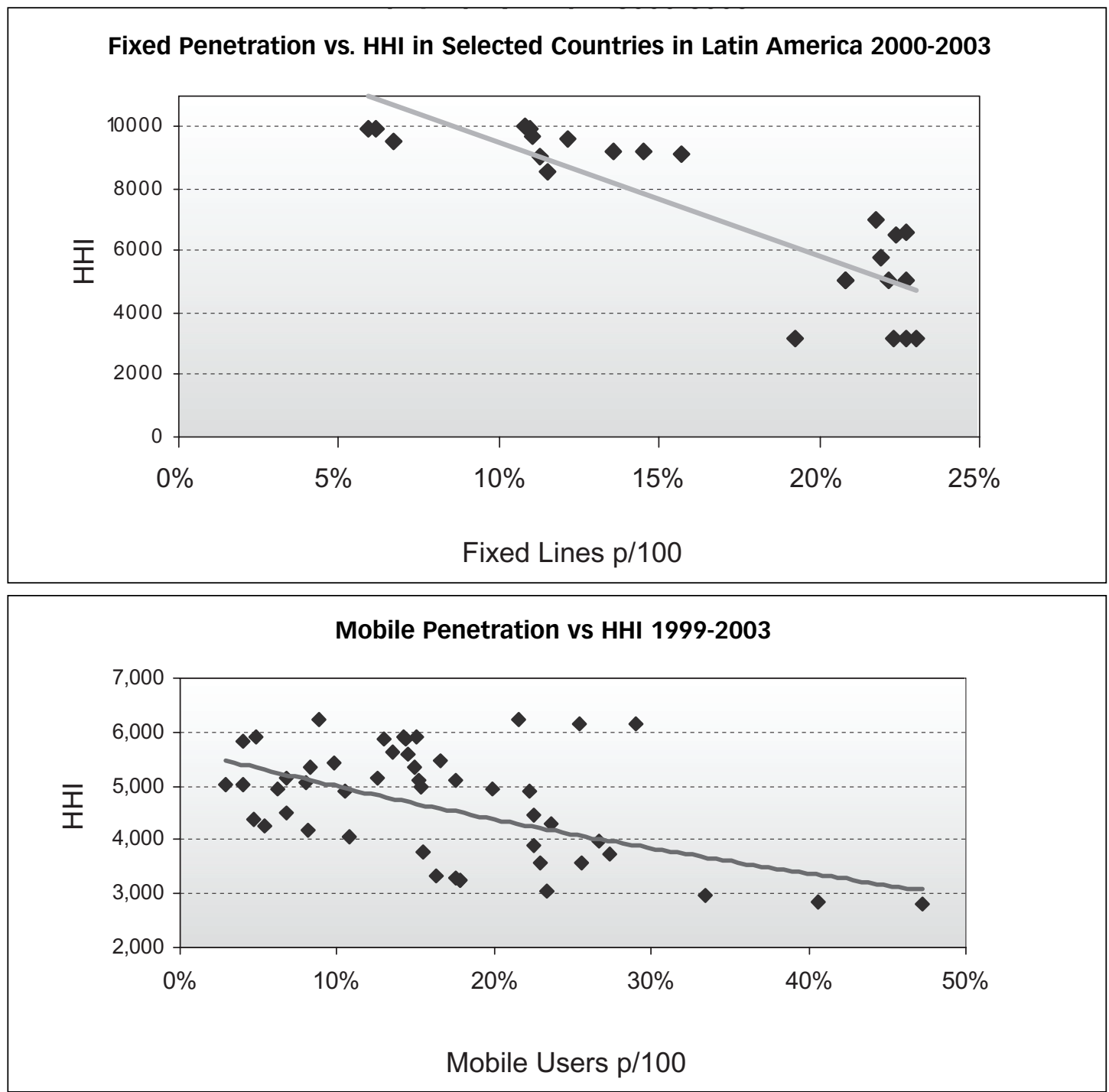

Source: Telecom-CIDE based on companies' information and regulators' Web pages. 
same year, mobile telephone services, as an alternative market, together with changes in technology began to experience an accelerated process of growth, creating great expectations in terms of foreign investment and business opportunities, enjoying the advantage of a lesser regulatory dependence and the need for survival of the dominant fixed telephone service companies.

The perspective for the sector's performance, within a regional duopoly in the making, presents the potential difficulties that are usually associated with this phenomenon in terms of price, service quality and network expansion (Shy, 1995). In a merely descriptive analysis, the observed data of concentration, measured by using the Herfindahl-Hirschman Index (HHI) ${ }^{3}$ and its relationship to the performance of telephone services as measured using the teledensity recorded in both segments, were studied. The following Figures 2.4 and 2.5 show that high HHI levels are associated with relatively lower teledensity levels. The same applies for fixed as well as mobile telephone services.

While the data presented are not conclusive and require a greater methodological rigor, it can be inferred that there is a negative relationship between both indicators, which is shown most significantly in the case of fixed telephone services, that is a market traditionally operated by companies with high concentrations at national or regional level. In the case of the mobile telephone market, this relationship has been developed from a higher level of competition, and currently has a better performance level in comparison to fixed telephone services, as will be documented in the following section of this essay.

In 2001, the market experienced an important change in almost all countries in the region. The overtaking fixed telephone services by mobile telephone services was driven mainly by the introduction of the pre-paid system and "Caller Party Pays" (CPP), that was part of the redesign process of the companies' business model. In 2000-2003, the average growth in users of mobile telephony was $33 \%$ in the region, while that of traditional telephone services recorded a much lower 7\%. In this new scenario, the telecommunications market entered into a consolidation process where mobile telephone services became the main focus of the two major operators in the region: América Móvil and Telefónica Móviles. The acquisition process of these two companies involved an aggressive campaign to attract customers and the depredation of local markets fighting for the regional positioning, even at the expense of lowering the revenues per user. Chart 2.6 shows a reduction in the Average Revenues Per User (ARPU) during this period, both in the total amount as well as in ARPU per

${ }^{3}$ The Herfindahl-Hirschman Index is a measure generally accepted to determine the market concentration level. It is computed based on the sum of the squared market share of each company; the indicator assigns values between 0 and 10,000, where the greater the value, the higher the market concentration. 
Figure 2.6 Average Revenues Per User in Latin America (ARPU)

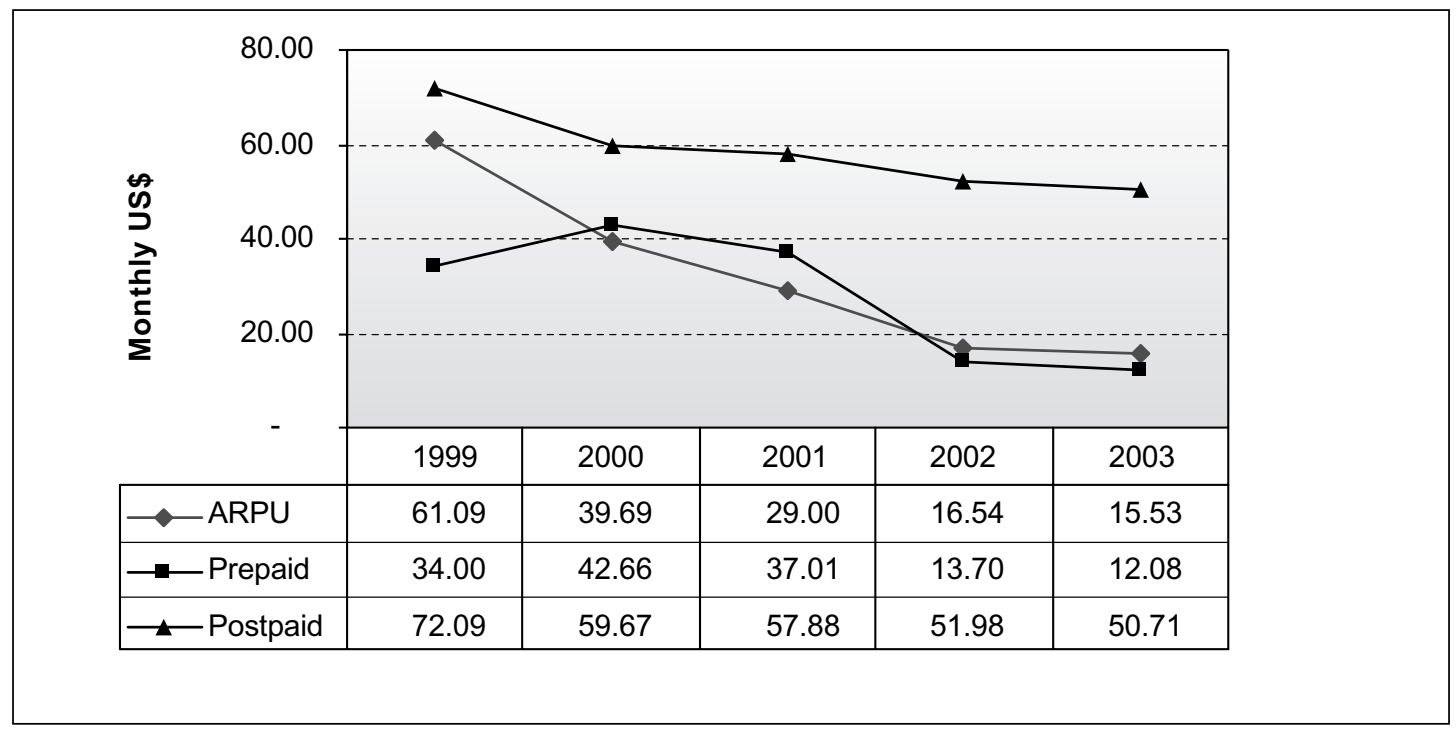

Sources: Telecom Data-CIDE based on ITU World Telecommunication Indicators 2004 and World Development Indicators 2004.

service, together with an increase in the user base. This indicates the presence of a global survival scenario and not an alliance between companies.

\section{The Role of Mobile Telephone Services ${ }^{4}$}

In recent years, in the region and in the world, mobile telephone services show a level of dynamism and growth that is much greater than that of fixed telephone services. This contributes to significantly increase access to telecommunications services. However, universal access policies continue to focus on promoting fixed line connectivity and Internet access.

The introduction of mobile telephones in the region has contributed to significantly increasing the access to telecommunications services, and thus it has helped to close the digital divide. Figure 3.1 illustrates the evolution of fixed and mobile telephone services in the region, while Figure 3.2 shows the evolution in the amount of mobile users per fixed line. With no exceptions, the countries involved in the sample show a tendency to an increase in mobile users per fixed line, particularly Mexico and Chile, where a higher volume of mobile users in contrast to fixed users can be observed since 1999.

${ }^{4}$ In strict technological terms, cellular and mobile telephones are different. Mobile telephone services include cellular telephone services (which operate in 800 or $1900 \mathrm{MHz}$ bands) more than any other technology that is not operated in these bands, such as trunking. However, in this essay both terms are used indistinctively. 
Figure 3.1: Mobile vs. Fixed Penetration in Selected Countries

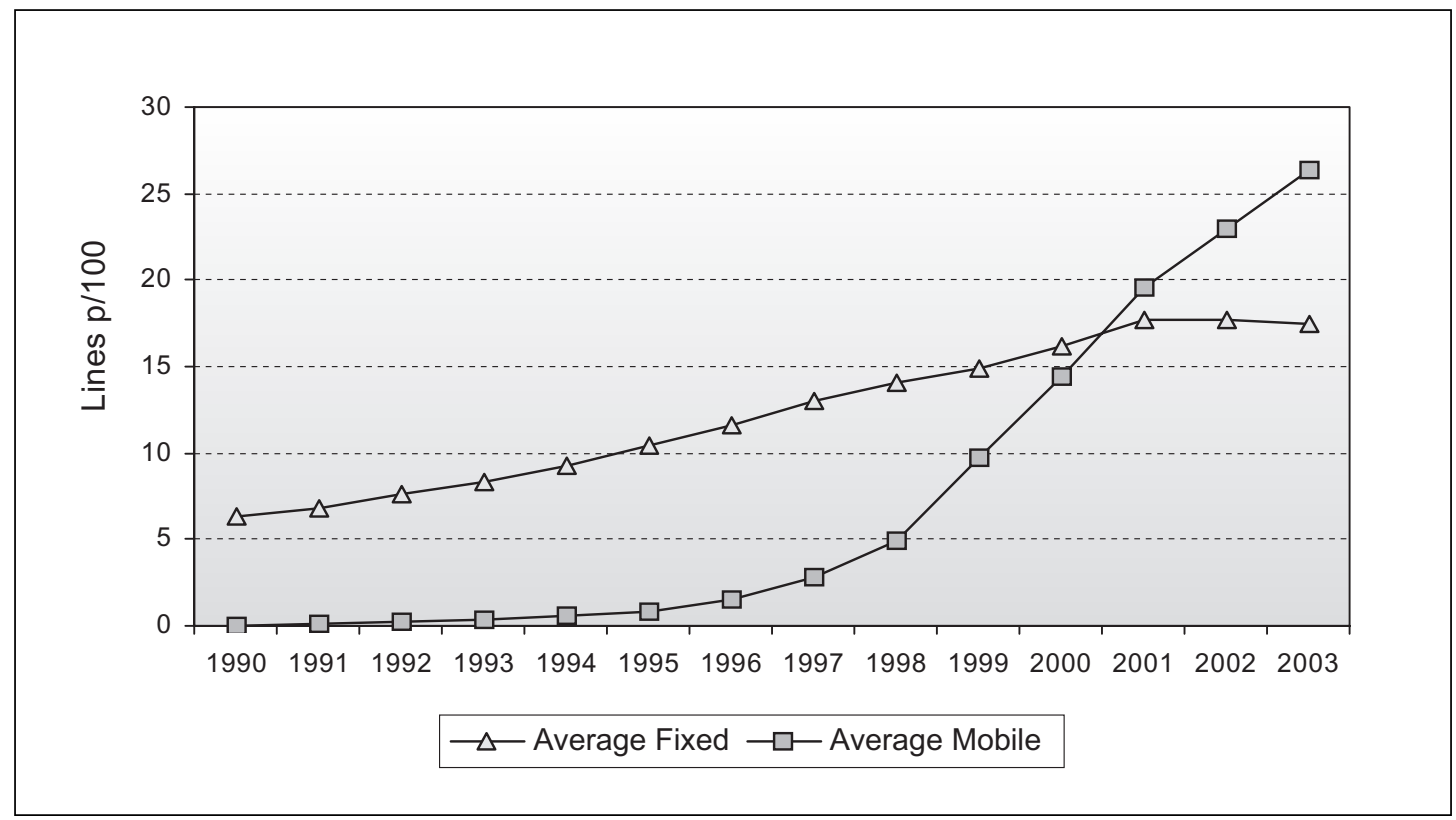

Source: Telecom-DATA based on ITU and data obtained from regulators. Note: Average teledensity corresponds to the five countries involved in the sample (Argentina, Brazil, Chile, Mexico and Peru).

Figure 3.2: Mobile Phones Per Fixed Line - Mexico and Selected Countries in Latin America

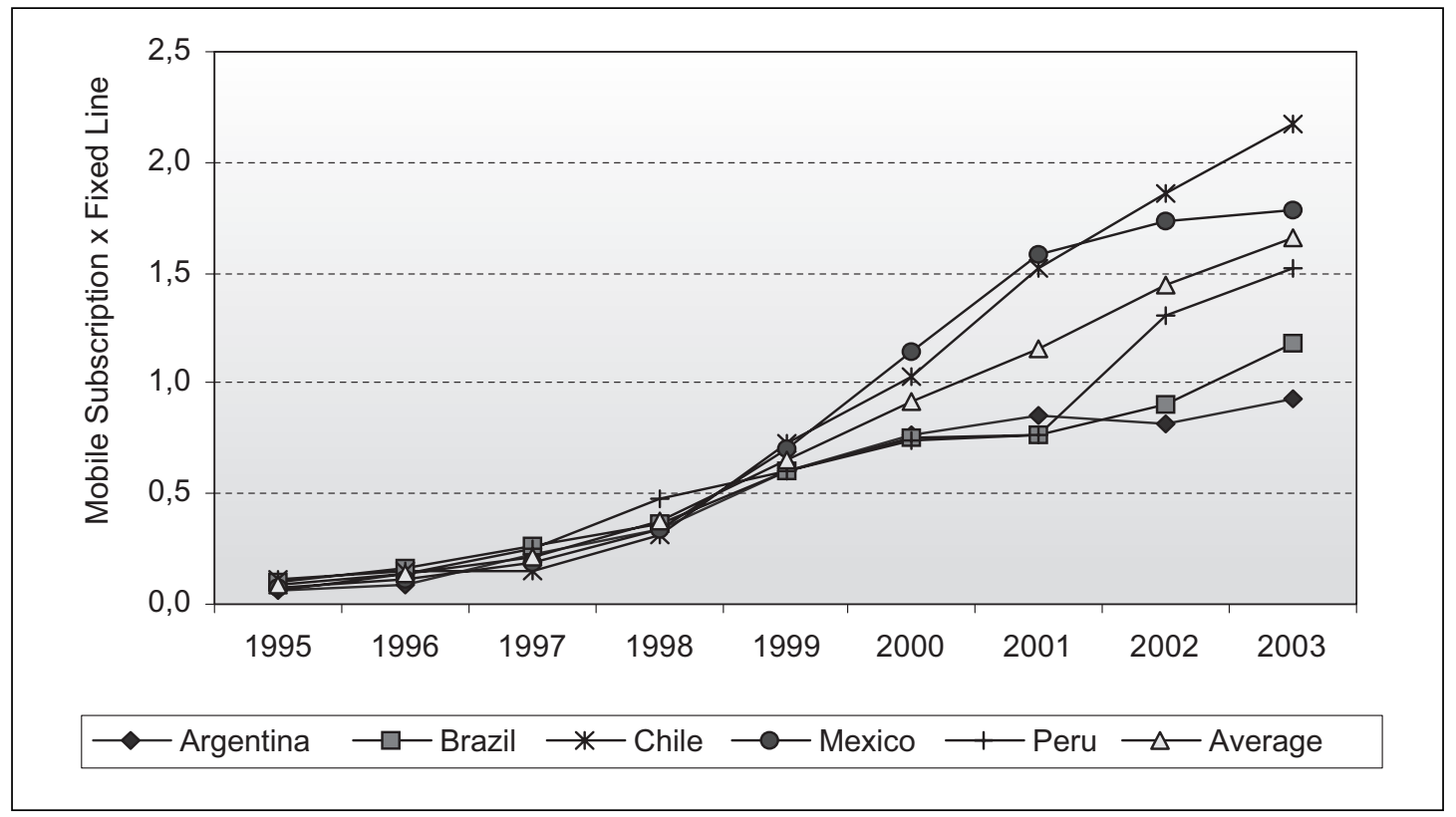

Source: Telecom-DATA based on ITU and data obtained from regulators and operators. 
A phenomenon that has certainly contributed to the increase in mobile and cellular growth in the region is the new pricing structure: the pre-paid card and "Caller Party Pays" (CCP. Clearly, the pre-paid option in Latin America has become a very powerful tool to encourage universal access, due to its convenience for lower income population segments. As illustrated in Chart 3.3, four of every five users in the region choose the pre-paid option over any other plan. In the case of Mexico, the difference is even more significant, since over $90 \%$ of users prefer this option.

Figure 3.3 Pre-Paid Mobile Telephone Services in the Region

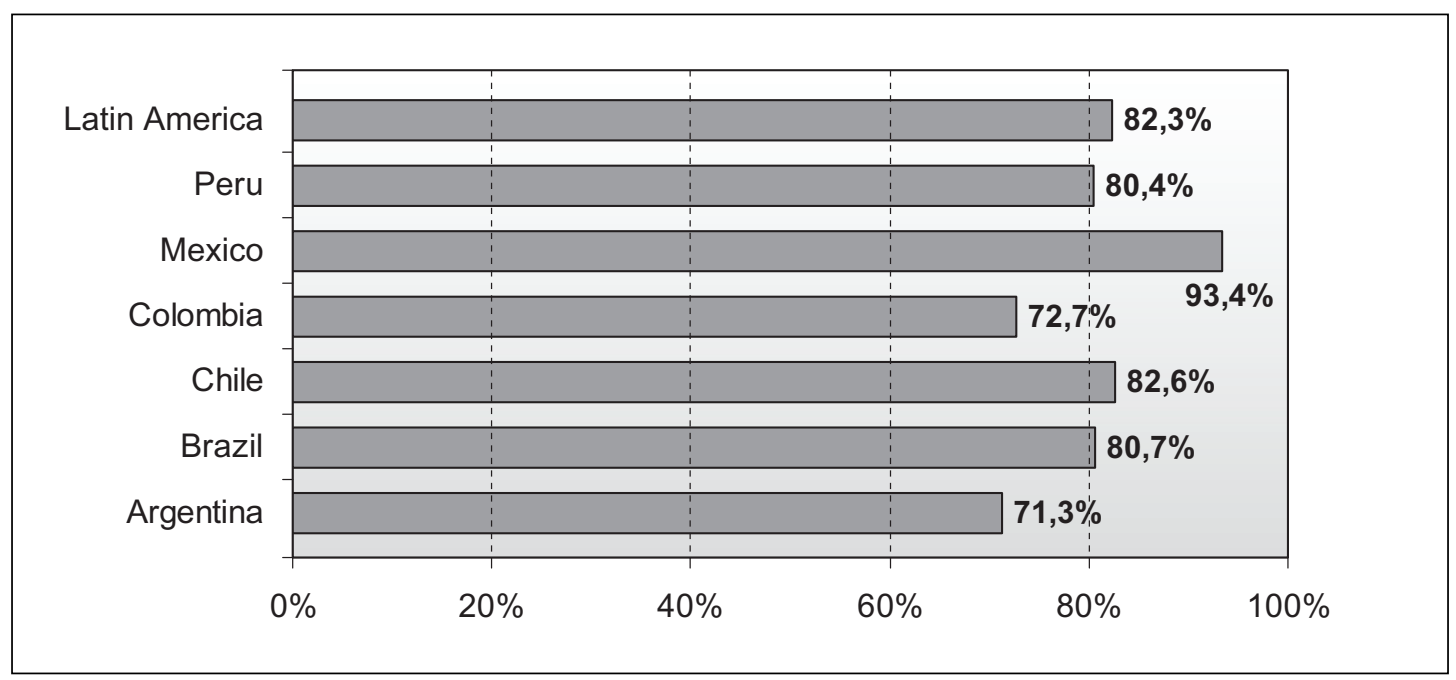

Source: Telecom-DATA based on data from operators and regulator's Web page.

Several current studies highlight the advantages of mobile telephone services over traditional telecommunications access, which offer fixed telephone services for low consumption users (Dymond \& Oestman, 2004; NECG, 2004; Stephens et al., 2005; Oestman, 2003). One of these advantages is the lower activation cost for the user in the case of mobile services (line activation, SIM card, equipment, etc.), as compared to fixed telephone services.

Another advantage consists of the alternatives offered by the pre-paid option, which allows the user to control costs and avoid signing a contract, thus not having to demonstrate a good credit history. For the operator it means not having to send monthly account balances and avoiding the risk of users failing to make contract payments.

The following table compares the initial and the monthly usage costs for users with low fixed and mobile telephone consumption in some countries in Latin America. 
Table 3.1: Cost Contrast between Fixed and Mobile Telephone Services for Low Consumption Users

\begin{tabular}{|l|c|c|c|c|}
\hline & \multicolumn{2}{|c|}{ Initial Cost } & \multicolumn{2}{c|}{ Monthly Cost/ Calls } \\
\hline & $\begin{array}{c}\text { Fixed } \\
\text { Telephone }\end{array}$ & $\begin{array}{c}\text { Mobile } \\
\text { Telephone }\end{array}$ & $\begin{array}{c}\text { Fixed } \\
\text { Telephone }\end{array}$ & $\begin{array}{c}\text { Mobile } \\
\text { Telephone }\end{array}$ \\
\hline Argentina & $\$ 150$ & $\$ 50,0$ & $\$ 13.65$ & $\$ 7,95$ \\
\hline Brazil & $\$ 27$ & $\$ 40,0$ & $\$ 7.90$ & $\$ 4,50$ \\
\hline Chile & $\$ 43$ & $\$ 67,1$ & $\$ 11,40$ & $\$ 8,10$ \\
\hline Colombia & $\$ 168$ & $\$ 49,25$ & $\$ 3,70$ & $\$ 4,20$ \\
\hline Mexico & $\$ 119$ & $\$ 46,2$ & $\$ 16,25$ & $\$ 6,90$ \\
\hline Peru & $\$ 131$ & $\$ 60,4$ & $\$ 13,95$ & $\$ 4,50$ \\
\hline Venezuela & $\$ 102$ & $\$ 54,0$ & $\$ 11,6$ & $\$ 6,15$ \\
\hline Average & $\$ 105,71$ & $\$ 52,42$ & $\$ 11,21$ & $\$ \$ 6,04$ \\
\hline
\end{tabular}

Note: Amounts in Dollars. Source: Oestman 2003.

Apart for a few exceptions, in all cases mobile telephone services have lower costs, in terms of initial costs as well as usage costs. On average, as shown in Table 3.1 , the cost of mobile telephone services is close to half that of fixed telephone services. Once more, it is important to highlight that these conclusions are only valid for low consumption users, as previously stated.

In a study carried out about cellular and mobile growth in Mexico by socio-economic levels (SEL), it can be observed that although mobile telephones are still predominant in high income sectors of the population, mobile telephone services have become a popularly used tool among low income sectors of the population. While in 2003 only $9 \%$ of the individuals in socio-economic levels $\mathrm{D}$ and $\mathrm{E}^{5}$ had a mobile telephone, in 2005 that amount had tripled to $27 \%$.

Table 3.2: Socio-Economic Level and Mobile Penetration in Mexico - 2005

\begin{tabular}{|l|c|c|c|c|c|}
\hline & $\begin{array}{c}\text { Level } \\
\text { A/B }\end{array}$ & $\begin{array}{c}\text { Level } \\
\text { C+ }\end{array}$ & $\begin{array}{c}\text { Level } \\
\text { D+ }\end{array}$ & $\begin{array}{c}\text { Level } \\
\text { D }\end{array}$ & $\begin{array}{c}\text { Level } \\
\text { E }\end{array}$ \\
\hline Population distribution & $10.8 \%$ & $9.1 \%$ & $23.8 \%$ & $56.3 \%$ & \\
\hline Postpaid system & $28 \%$ & $12 \%$ & $6 \%$ & $6 \%$ & $4 \%$ \\
\hline Prepaid system & $72 \%$ & $88 \%$ & $94 \%$ & $94 \%$ & $96 \%$ \\
\hline $\begin{array}{l}\text { Total users } \\
\text { (over group total) }\end{array}$ & $89 \%$ & $75 \%$ & $67 \%$ & $42 \%$ & $27 \%$ \\
\hline
\end{tabular}

Note: The highest SEL level is "A" while "E" represents the most marginalized population sector in Mexico. Source: Telecom CIDE (2005).

${ }^{5}$ According to Mexico's SEL methodology, level "A" represents the wealthiest sector of the population, while level "E" is the poorest and most marginalized sector. 
In 2005, the population segments that used the prepaid system the most were the users of SELs D and E. In addition to lower access costs, the option of having a personal device for communication offers individuals within the poorest sectors an

Figure 3.4: Mobile Users under the Pre-paid Plan by Socioeconomic Level

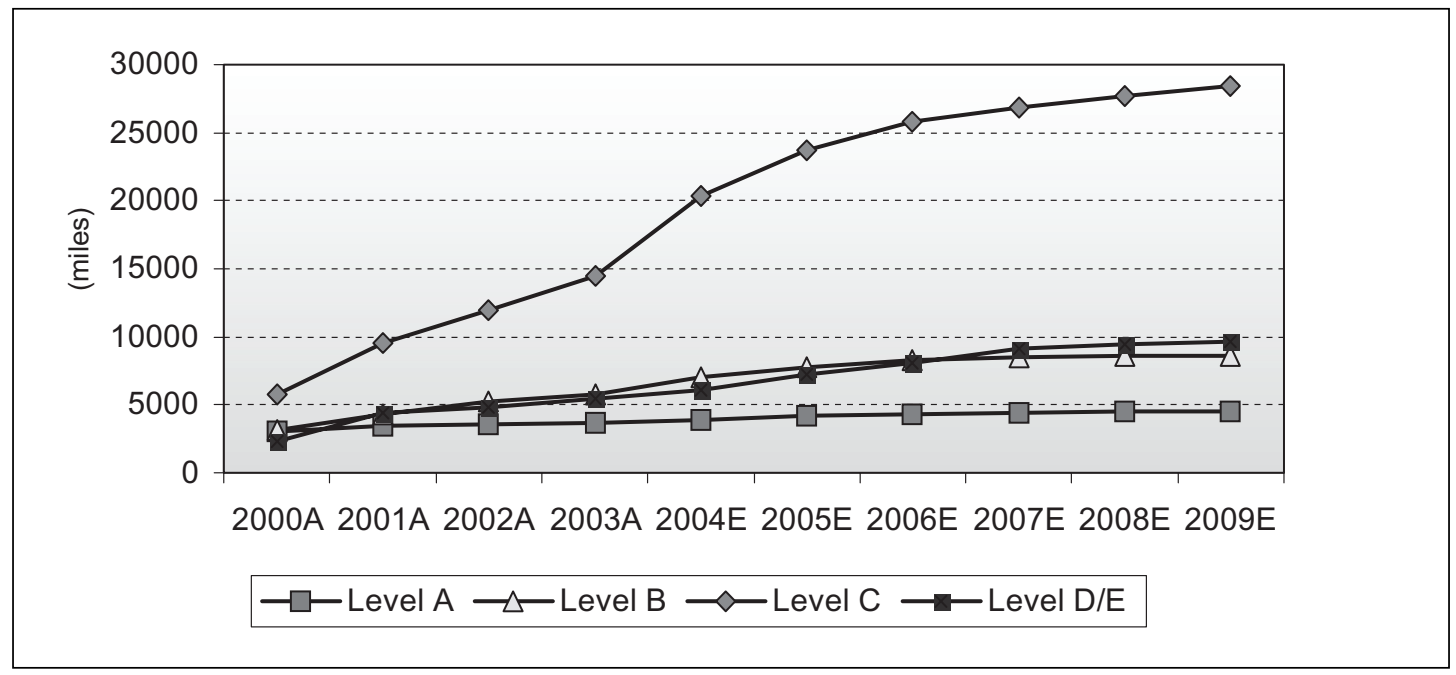

Source: Own study on projective data provided by Telefónica Movistar, Mexico.

Figure 3.5': Pre-paid Users by SEL 2002-2009

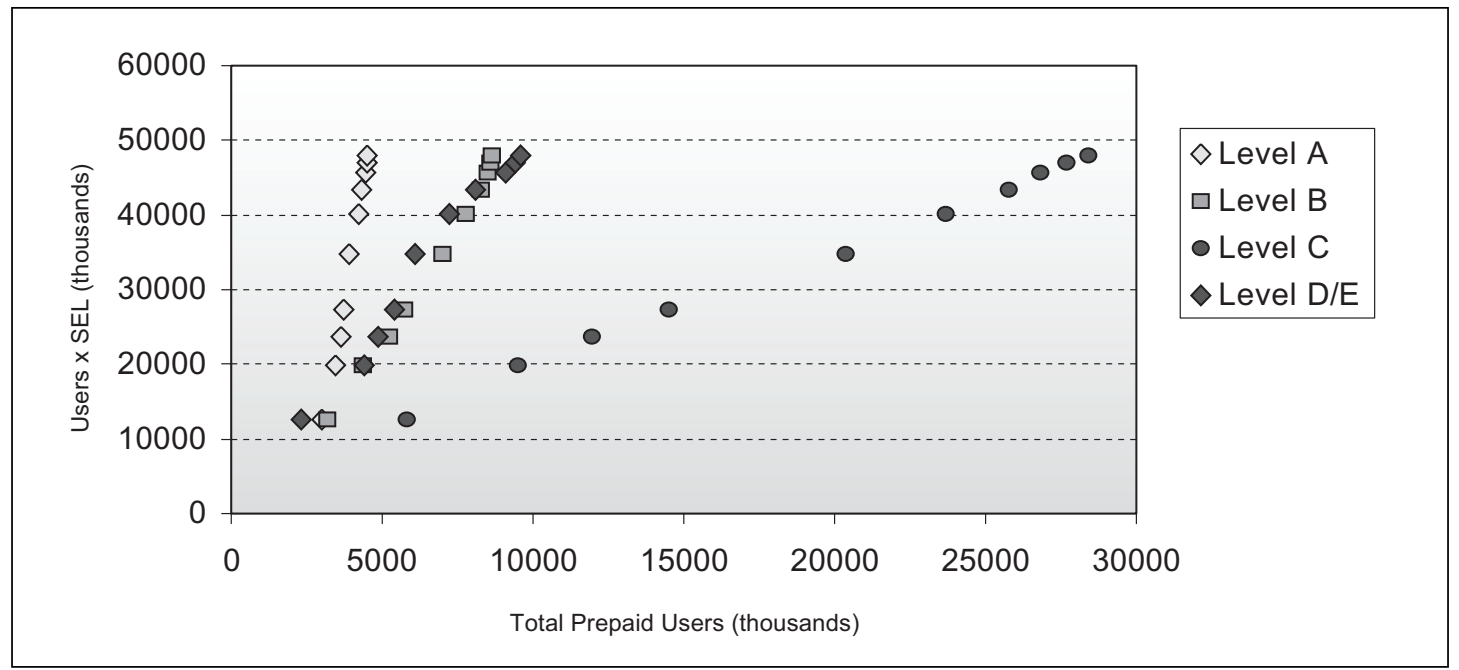

Source: Own study on projective data provided by Telefónica Movistar, Mexico.

${ }^{6}$ Chart 3.5 shows the relationship between the number of users according to their socio-economic level (SEL) and the total of prepaid system users over 9 years. For example, green dots indicate the number of users of SEL C and the total of prepaid system users for each year from 2000 to 2009. 
independence that is not available from other types of access to communication, such as community centers, which often limit the possibility of receiving calls. The possibility to be reached should also be taken into account, since it plays a major role in terms of use, if we consider that temporary work is usually the predominant form of employment among low income sectors.

In the case of Mexico, Figures 3.4 and 3.5 show the mobile telephone contribution to service middle and low income groups in the country.

In all cases, the middle class, associated with socio-economic level $\mathrm{C}$, will have the highest increase in total users in the coming years, compared to total prepaid system users. In addition, the time projection shows that after level $\mathrm{C}$, the lowest income population sector will be the one with the highest growth in the amount of users under the prepayment plan. Thus, the prepaid system is clearly predominant and allows low income users to have access to telecommunications services, offering opportunities for using such devices as a means of payment or as the mean to access other services in the future.

Regarding rural or isolated areas, due to the same payment system characteristics, but mainly due to technological, and thus cost reasons, today mobile telephony is the more viable model to respond to the demand for telecommunications services. As Navas-Sabater et al. (2002) pointed out, wireless networks offer significant cost advantages over fixed telephone services, particularly when offering services to isolated communities as well as to small towns. According to these authors, the special features provided by the mobile network (speed and ease of equipment deployment, as well as the absence of wires) make these networks a more efficient solution than fixed telephone services, especially when servicing isolated or remote communities (Navas-Savater et al., 2002). ${ }^{7}$

\section{Conclusions}

The reforms implemented in the telecommunications sectors in Latin America translated into an increase in the adoption of technology, in business efficiency and network expansion, at the same time lowering fees. In general terms, the industry's performance today is remarkably superior. However, the task still remains of offering the benefits of modern life to society's marginalized sectors. In Latin America there are still several segments of society that do not have access to basic telecommunications services.

This task should be tackled, considering that the region is currently facing the clear presence of a regional duopoly Telefónica Móviles and América Móvil-Telmex

\footnotetext{
${ }^{7}$ For more details, please refer to chapter 5 by by Galperin and Girard, which focus on this topic from a particular perspective.
} 
enjoy a great and powerful position in the region. Telefónica has become the main provider of telecommunications services in most South American markets. América Móvil and Telmex have a dominant presence in Mexico and Central America and continue acquiring markets in South America. Both companies are going through deep merging and acquisition processes, making it difficult to forecast who will be the ultimate winner in the region.

What we can observe until now is that both companies have shown global survival strategies, and in some cases have sacrificed profits while fighting for their positioning in the market. As long as the Latin American market is still growing, either from unmet demand or from demand for new services, it is foreseeable that competition and not collusion will prevail. Nevertheless, it can be expected that the two companies will develop a cooperation strategy in the future. Faced with this possibility, it would be necessary to evaluate if the governments of the region should consider a region-wide regulatory strategy. This is an area for future research that should take into account economic, political and institutional differences among the Latin American countries.

Lastly, the regulatory answer to a new market context should also include the fact that mobile telephone services have become the predominant way of communication in the region. Moreover, mobile telephone services represent today an affordable means of communication for low income segments of the population. The strategies adopted by companies such as the "Caller Party Pays" program seem to have achieved more than the universal access programs carried out by the governments aiming at increasing the use of telecommunications. How should regulations encourage these types of strategies? Future research should re-evaluate the private sector's role in distributing the benefits of new information technologies to most population segments. 


\section{References}

Dymond, A. \& Oestman, S. (2004). The role of sector reform in achieving universal access. Trends in Telecommunication Reform 2003, chapter 3. Geneva: ITU.

García-Murillo, M. \& Kuerbis, B. (2004). The effects of institutional constraints on the success of universal service policies: A comparison between Latin America and the World. Mimeo.

Gutierrez, L. H. (2003). The effects of endogenous regulation on Telecommunications expansion and efficiency in Latin America. Journal of Regulatory Economics (23) 257-286.

Li, W. \& Colin Xu, L. (2002). The Impact of Privatization and Competition in the Telecommunications Sector around the World. World Bank Working Paper, October. Washington, D.C.: The World Bank.

Mariscal, J. \& Rivera, E. (2005). New trends in the Latin American telecommunications market: Telefonica \& Telmex. Telecommunications Policy, 29(9-10), 757777.

Navas-Savater, J., Dymond A. \& Juntunen, N. (2002). Telecommunications and Information Services for the Poor: Toward a Strategy for Universal Access. The World Bank Group. World Bank Discussion Paper No. 432. Washington, D.C.: The World Bank.

Network Economics Consulting Group NECG. (2004).The Diffusion of Mobile Telephony in Latin America, Successes and Regulatory Challenges. Canberra: NECG.

Oestman, S. (2003). Mobile Operators: their contribution to universal service and public access. Intelecon Research. Retrieved July, 2005, from http://www.inteleconresearch.com/pdf/mobile\%20\&\%20us\%20-\%20for\%20rru.pdf

Shy, O. (1995). Industrial Organization: Theory and Application. Cambridge, MA: The MIT Press.

Stephens, R., Boyd, J. \& Galarza, J. (2005). Telefonía celular: nuevo instrumento para el acceso universal en Latinoamérica. Latin.tel Regulatel, 1 (1). Retrieved April, 2005, from http://www.regulatel.org/publica/Revista/Revista.pdf

Telecom CIDE. (2005). Contribuciones Sociales y Económicas de la Telefonía Móvil En México según un análisis de las fases de Maduración del Mercado. Elaborated for Telefónica Movistar Mexico.

Wallsten, S. J. (2000). Telecommunications, Privatization in Developing Countries: The Real Effects of Exclusivity Periods. World Bank Working Paper. Washington, D.C.: The World Bank.

Wallsten, S. J. (2001). An Econometric Analysis of Telecom Competition, Privatization, and Regulation in Africa and Latin America. The Journal of Industrial Economics, 49 (1).

Wallsten, Scott J. (2002). Does Sequencing Matters? Regulation and Privatization in Telecommunications Reforms. Development Research Group, The World Bank. Washington, D.C.: The World Bank. 
